\title{
Preparation and Performance of Continuous Glass Fiber Reinforced Polypropylene Composite Honeycomb Sandwich Panels
}

\author{
Ke CHEN ${ }^{\mathrm{a}}$, Ping XUE ${ }^{\mathrm{b}}$, Xiang $\mathrm{ZHOU}^{\mathrm{c}}$ and Mingyin JIA ${ }^{\mathrm{d}, *}$ \\ Institute of Plastic Machinery and Engineering, Beijing University of Chemical Technology, Beijing \\ 100029, China \\ aningxiaomeng0903@hotmail.com', bxueping@mail.buct.edu.cn, ${ }^{c}$ buctzx1209@126.com, \\ djiamy@mail.buct.edu.cn
}

\begin{abstract}
As the light-weight and high-strength thermoplastic composites, novel honeycomb sandwich panels were discussed in this paper: continuous glass fiber reinforced polypropylene (GF/PP) laminated sheets were used as the surface and polypropylene (PP) honeycomb was used as the core. The effects of honeycomb core's height, thickness and aperture on the mechanical properties were analyzed in this paper. The composite honeycomb sandwich panels exhibited excellent bending strength at $37.6 \mathrm{MPa}$ and lateral pressure strength at $25.8 \mathrm{MPa}$.
\end{abstract}

\section{Introduction}

Fiber reinforced polymer composites are consisting of polymer matrix and high-strength fiber, such as glass fiber (GF) and carbon fiber [1]. Fiber reinforced polymer composites can be divided into fiber reinforced thermosetting composites and fiber reinforced thermoplastic composites. However, Fiber reinforced thermoplastic composites can offer some substantial advantages over thermoset ones, namely low cost, recyclability, and short cycle time [2]. Because of the relative simplicity and high efficiency of manufacturing process, continuous fiber reinforced thermoplastic composites are now widely used in various industrial fields $[3,4]$.

In recent years, continuous GF/PP composite thermoplastic sheet (panel) received many researchers' attention and plenty of researches were reported in literature [5-9]. For example, Research of J.P.Dear et al. [10] was about the impact toughness of honeycomb sandwich panels prepared from sheet molding compound (SMC), glass mat thermoplastic (GMT) and different skin and core materials. It was shown that SMC sandwich panels have the highest impact energy absorbed, since GF content of SMC is up to $62 \%$. Haibin Ning et al. [11] used GF/PP woven tape as the surface sheet material and used PP honeycomb as the core to manufacture a thermoplastic sandwich body panel for a mass transit bus. The debonding between the interior and exterior face sheet resulted in the part failure when the loading reached to $11.7 \mathrm{kN}$. Moreover, carbon fibre/matrix composite honeycomb panel was prepared by Chun $\mathrm{Lu}$ et al. [12] with compression molding technique. Compared with

* Corresponding author:ningxiaomeng0903@hotmail.com 
traditional aluminum and Nomex honeycomb Sandwich panel, carbon fibre/epoxy Honeycomb Sandwich panel has higher bending strength.

This article discusses the usage of GF/PP laminated sheets for the manufacturing of three kinds of honeycomb sandwich panels through hot press. An additional outcome of this study is to analyze the process parameters and their effects on the tensile properties, bending properties and lateral pressure properties of the honeycomb sandwich panels.

\section{Experimental Procedure}

PP supplied by Sinopec (China), GF from Jushi Group (China) and GF commingled yarn from Xuanlei Composite were used in this study to manufacture laminated sheets as the surface of the honeycomb sandwich panels. The glass fiber was directly roving with 2400 tex. In addition, PP honeycomb cores with different parameters, which were the production of Tubo Plate (China), were used as the interlayers of the honeycomb sandwich panels.

Continuous GF/PP unidirectional impregnated sheets were prepared by the method of melt impregnation. The PP matrix was melted and extruded to the dipping mold by a double screw extruder. There were grooves in the dipping mold with different depths. The dispersion was realized by pulling glass fiber through the dipping roller. Impregnated fiber was pulled out of the mold and then cooled and shaped. Thus, continuous GF/PP unidirectional dipping sheet was prepared with the fiber mass content of $60 \%$, which was shown in Fig. 1 (a).

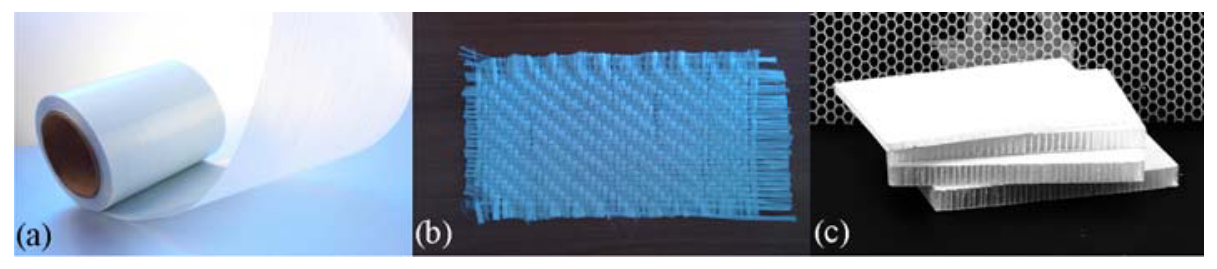

Fig. 1 Continuous GF/PP unidirectional dipping sheet (a), continuous GF/PP commingled yarn laminated sheet (b) and PP honeycomb (c).

Three kinds of continuous GF/PP laminated sheets (continuous GF/PP unidirectional $\left(0^{\circ} / 0^{\circ}\right)$ laminated sheet, continuous $\mathrm{GF} / \mathrm{PP}$ cross $\left(0^{\circ} / 90^{\circ}\right)$ laminated sheet and continuous $\mathrm{GF} / \mathrm{PP}$ commingled yarn laminated sheet) were manufactured, which were intended as the surfaces of honeycomb sandwich panels.

Self-prepared continuous GF/PP unidirectional impregnated sheets were cut in $200 \times$ $200 \mathrm{~mm}$ size and sequenced placed according to different layers and different angles. There was a hot press at $220^{\circ} \mathrm{C}, 5 \mathrm{MPa}$ for $15 \mathrm{~min}$. Then cool down the sheets with $5 \mathrm{MPa}$ until room temperature.

Next was the preparation of commingled yarn laminated sheets. The acquired glass fiber commingled yarn was woven crosswise and each commingled yarn contained reinforced fiber and PP fiber (fiber mass content was also 60\%). Process conditions were the same as the above. Continuous GF/PP commingled yarn laminated sheet was shown in Fig. 1 (b) and PP honeycomb was also shown in Fig. 1 (c).

Finally, it would be the preparation of the honeycomb sandwich panels. Continuous GF/PP laminated sheets and honeycomb core were placed according to the structure of sandwich. Through hot press, the consolidation between sheets and honeycomb core was realized. Molding conditions were $210^{\circ} \mathrm{C}$ and $0.5 \mathrm{MPa}$ for $25 \mathrm{~s}$. Then there would be a cold 
press with $0.5 \mathrm{MPa}$ until room temperature. Thus, three kinds of honeycomb sandwich panels would be manufactured.

\section{Results and Discussion}

Height of honeycomb core. Only change the honeycomb core's height to produce three kinds of honeycomb sandwich panels (3 layers) and test their flat pressure performance. Aperture of the honeycomb core was $8 \mathrm{~mm}$ and wall thickness was $0.6 \mathrm{~mm}$. Results were shown in Fig. 2.
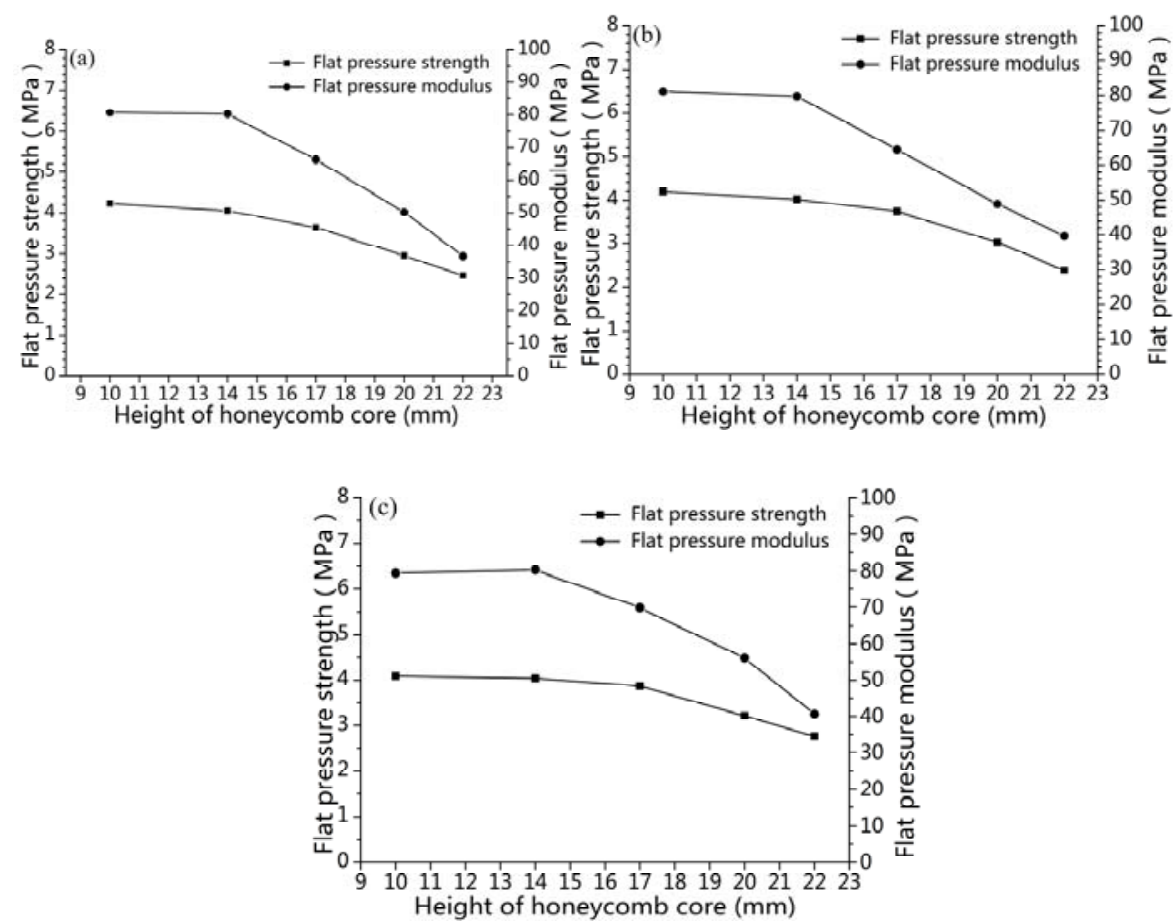

Fig. 2 Commingled yarn honeycomb sandwich panel(a), unidirectional $\left(0^{\circ} / 0^{\circ}\right)$ laminated honeycomb sandwich panel(b) and cross $\left(0^{\circ} / 90^{\circ}\right)$ laminated honeycomb sandwich panel(c).

It was seen that the flat pressure strength of these three kinds of honeycomb sandwich panels decreased with the height's increase. The maximum flat pressure strength was 4.2MPa. The equation of flat pressure modulus of the honeycomb sandwich panel [13] was followed.

$$
\frac{1}{E_{z}}=\frac{2 t}{E_{f z}(h+2 t)}+\frac{h}{E_{c z}(h+2 t)}
$$

In which $h$ and $t$ are the height of honeycomb core and thickness of panel. $E_{z}$ is vertical flat modulus of honeycomb sandwich panel, $E_{f z}$ is vertical modulus of panel, and $E_{c z}$ is the vertical modulus of honeycomb core.

$E_{z}$ can be calculated according to the Eq. 1 . 


$$
E_{z}=\frac{E_{f z} E_{c z}(h+2 t)}{2 t E_{c z}+E_{f z} h}
$$

In terms of $h$ as independent variables of $E_{z}$, partial differential equation can be obtained.

$$
\left(E_{z}\right)_{h}^{\prime}=\frac{2 E_{f z} E_{c z}\left(E_{c z}-E_{f z}\right)}{\left(2 E_{c z} t+E_{f z} h\right)^{2}}
$$

Since $E_{f z} \gg E_{c z}>0$ and $\left(E_{z}\right)_{h}{ }^{\prime}<0$, flat modulus of the honeycomb sandwich panel was negative correlated with the height. Therefore, its flat pressure performance decreased with the increase of the height of honeycomb core.

Bending performance was also tested and recorded.
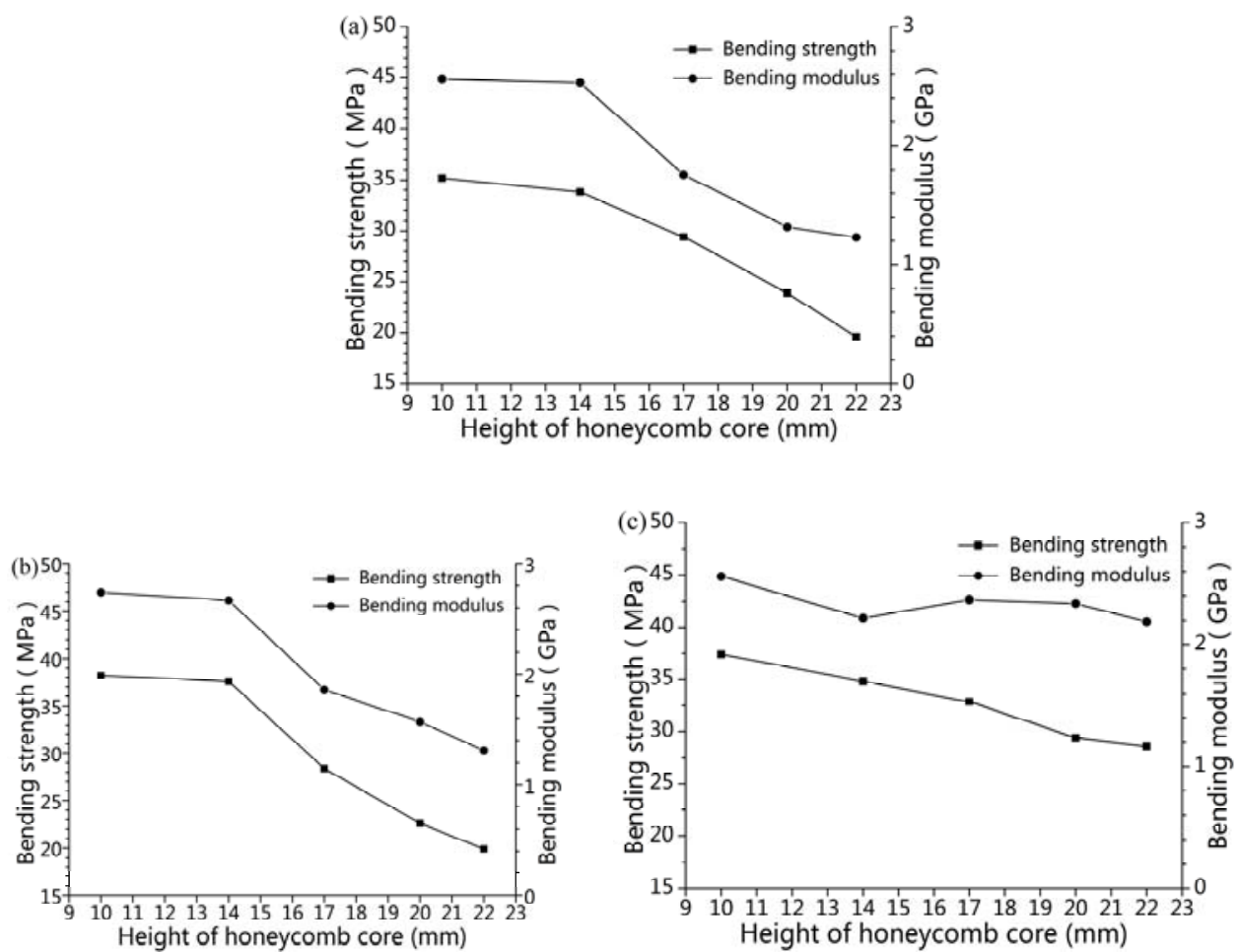

Fig. 3 Commingled yarn honeycomb sandwich panel(a), Unidirectional $\left(0^{\circ} / 0^{\circ}\right)$ laminated honeycomb sandwich panel(b) and Cross $\left(0^{\circ} / 90^{\circ}\right)$ laminated honeycomb sandwich panel(c).

From Fig. 3, bending performance of the three kinds of honeycomb sandwich panels also decreased with the increase of the height. It was indicated that bending crack was caused by lateral shear failure of the honeycomb core. By Eq. 4, shear modulus of honeycomb sandwich panel could be calculated [13]. 


$$
G_{x y}=G_{f x y} \frac{2 t}{h+2 t}
$$

In which $G_{x y}$ and $G_{f x y}$ are shear modulus of honeycomb sandwich panels and shear modulus of the surface sheets. The shear modulus of the honeycomb sandwich panels decreased with the increase of the height, which made high composite honeycomb core more prone to bending deformation.

Lateral pressure performance of different honeycomb core heights was tested. The results were shown in Table 1.

TABLE 1 LATERAL PRESSURE PERFORMANCE OF DIFFERENT HONEYCOMB CORE HEIGHTS

\begin{tabular}{|c|c|c|c|c|c|c|}
\hline \multirow{2}{*}{ Type } & \multicolumn{6}{|c|}{ Height of honeycomb core $/ \mathrm{mm}$} \\
\hline & & 10 & 14 & 17 & 20 & 22 \\
\hline \multirow{3}{*}{$\begin{array}{l}\text { Commingled yarn } \\
\text { honeycomb sandwich panel }\end{array}$} & Lateral pressure & 15. & 14. & 13. & 10. & 9.6 \\
\hline & strength/MPa & 2 & 3 & 2 & 2 & 3 \\
\hline & $\begin{array}{c}\text { Lateral pressure } \\
\text { modulus/MPa }\end{array}$ & 597 & 589 & 577 & 387 & 324 \\
\hline \multirow{2}{*}{$\begin{array}{l}\text { Unidirectional }\left(0^{\circ} / 0^{\circ}\right) \\
\text { laminated honeycomb } \\
\text { sandwich panel }\end{array}$} & $\begin{array}{c}\text { Lateral pressure } \\
\text { strength/MPa }\end{array}$ & $\begin{array}{c}16 . \\
5\end{array}$ & $\begin{array}{c}15 . \\
3\end{array}$ & $\begin{array}{c}12 . \\
6\end{array}$ & $\begin{array}{c}11 . \\
1\end{array}$ & $\begin{array}{c}10 . \\
7\end{array}$ \\
\hline & $\begin{array}{c}\text { Lateral pressure } \\
\text { modulus/MPa }\end{array}$ & 462 & 420 & 367 & 321 & 317 \\
\hline \multirow{2}{*}{$\begin{array}{l}\text { Cross }\left(0^{\circ} / 90^{\circ}\right) \text { laminated } \\
\text { honeycomb sandwich panel }\end{array}$} & $\begin{array}{c}\text { Lateral pressure } \\
\text { strength/MPa }\end{array}$ & $\begin{array}{c}25 . \\
8\end{array}$ & $\begin{array}{c}24 . \\
9\end{array}$ & $\begin{array}{c}20 . \\
3\end{array}$ & $\begin{array}{c}18 . \\
7\end{array}$ & $\begin{array}{c}17 . \\
6\end{array}$ \\
\hline & $\begin{array}{c}\text { Lateral pressure } \\
\text { modulus/MPa }\end{array}$ & $\begin{array}{c}110 \\
7\end{array}$ & $\begin{array}{c}101 \\
9\end{array}$ & 967 & 944 & 869 \\
\hline
\end{tabular}

Lateral pressure strength and modulus decreased with the increase of honeycomb core's height, since honeycomb sandwich panels would produce compression deformation and bending deformation under the lateral load. The maximum lateral pressure strength was $25.8 \mathrm{MPa}$, which was shown at $10 \mathrm{~mm}$ of the honeycomb core.

Thickness of the honeycomb core. Only change the thickness of the honeycomb core, performance of three kinds of honeycomb sandwich panels (3 layers) was tested and recorded. The aperture of the honeycomb core was $8 \mathrm{~mm}$, height of honeycomb core was $14 \mathrm{~mm}$. Results were shown in Table 2. 
TABLE 2 PERFORMANCE OF DIFFERENT HONEYCOMB CORE THICKNESSES OF HONEYCOMB SANDWICH PANEL

\begin{tabular}{|c|c|c|c|c|c|c|}
\hline \multirow[t]{2}{*}{ Performance } & \multicolumn{2}{|c|}{$\begin{array}{l}\text { Commingled } \\
\text { yarn } \\
\text { honeycomb } \\
\text { sandwich panel }\end{array}$} & \multicolumn{2}{|c|}{$\begin{array}{c}\text { Unidirectional } \\
\left(0^{\circ} / 0^{\circ}\right) \text { laminated } \\
\text { honeycomb } \\
\text { sandwich panel }\end{array}$} & \multicolumn{2}{|c|}{$\begin{array}{c}\text { Cross }\left(0^{\circ} / 90^{\circ}\right) \\
\text { laminated } \\
\text { honeycomb } \\
\text { sandwich panel }\end{array}$} \\
\hline & $\mathrm{T}=0.4$ & $\mathrm{~T}=0.6$ & $\mathrm{~T}=0.4$ & $\mathrm{~T}=0.6$ & $\mathrm{~T}=0.4$ & $\mathrm{~T}=0.6$ \\
\hline Flat pressure strength $/ \mathrm{MPa}$ & 2.97 & 4.05 & 2.84 & 4.02 & 3.12 & 4.04 \\
\hline Flat pressure modulus/MPa & 64.7 & 80.3 & 60.4 & 79.8 & 70.6 & 80.2 \\
\hline Bending strength $/ \mathrm{MPa}$ & 20.2 & 33.8 & 26.2 & 37.6 & 20.7 & 34.8 \\
\hline Bending modulus/MPa & 1.96 & 2.53 & 2.15 & 2.67 & 1.27 & 2.22 \\
\hline Lateral pressure strength/MPa & 11.0 & 14.3 & 10.3 & 15.3 & 16.3 & 24.9 \\
\hline Lateral pressure modulus/MPa & 419 & 589 & 316 & 420 & 717 & 1019 \\
\hline Volume density $/ \mathrm{kg} \cdot \mathrm{m}^{-3}$ & 395 & 437 & 343 & 391 & 501 & 556 \\
\hline $\begin{array}{l}\text { Thickness of honeycomb } \\
\text { panel } / \mathrm{mm}\end{array}$ & 14.6 & 15.4 & 14.4 & 15.3 & 16.7 & 17.6 \\
\hline
\end{tabular}
mechanical property. It was also found that panels of same layers were got thinner with thinner honeycomb core. This was due to the process of hot press fusion. The thinner of the honeycomb wall, the panels more possible to collapse. Maximum bending strength was $37.6 \mathrm{MPa}$ when honeycomb core was $0.6 \mathrm{~mm}$.

Honeycomb core apertures. Performance of the honeycomb sandwich panels (3 layers) with different honeycomb core apertures was shown in Table 3. Thickness of the honeycomb core was $0.6 \mathrm{~mm}$, and height of honeycomb core was $14 \mathrm{~mm}$.

\section{TABLE 3 PERFORMANCE OF DIFFERENT HONEYCOMB CORE APERTURE OF} HONEYCOMB SANDWICH PANELS

\begin{tabular}{|c|c|c|c|c|c|c|}
\hline \multirow[t]{2}{*}{ Performance } & \multicolumn{2}{|c|}{$\begin{array}{c}\text { Commingled } \\
\text { yarn } \\
\text { honeycomb } \\
\text { sandwich } \\
\text { panel }\end{array}$} & \multicolumn{2}{|c|}{$\begin{array}{c}\text { Unidirectional } \\
\left(0^{\circ} / 0^{\circ}\right) \text { laminated } \\
\text { honeycomb } \\
\text { sandwich panel }\end{array}$} & \multicolumn{2}{|c|}{$\begin{array}{c}\text { Cross }\left(0^{\circ} / 90^{\circ}\right) \\
\text { laminated } \\
\text { honeycomb } \\
\text { sandwich panel }\end{array}$} \\
\hline & $\Phi=8$ & $\begin{array}{c}\Phi=1 \\
0\end{array}$ & $\Phi=8$ & $\Phi=10$ & $\Phi=8$ & $\Phi=10$ \\
\hline Flat pressure strength/MPa & 4.05 & 2.91 & 4.02 & 2.86 & 4.04 & 2.97 \\
\hline Flat pressure modulus/MPa & 80.3 & 67.4 & 79.8 & 62.3 & 80.2 & 70.9 \\
\hline Bending strength $/ \mathrm{MPa}$ & 33.8 & 22.4 & 37.6 & 26.4 & 34.8 & 21.1 \\
\hline Bending modulus/MPa & 2.52 & 1.76 & 2.67 & 2.03 & 22.2 & 18.2 \\
\hline
\end{tabular}




\begin{tabular}{ccccccc}
\hline $\begin{array}{c}\text { Lateral pressure } \\
\text { strength/MPa }\end{array}$ & 14.3 & 10.7 & 15.3 & 10.2 & 24.9 & 17.6 \\
\hline $\begin{array}{c}\text { Lateral pressure } \\
\text { modulus/MPa }\end{array}$ & 589 & 406 & 420 & 361 & 1019 & 743 \\
\hline Volume density $/ \mathrm{kg} \cdot \mathrm{m}^{-3}$ & 437 & 352 & 391 & 321 & 556 & 479 \\
\hline $\begin{array}{c}\text { Thickness of honeycomb } \\
\text { panel/mm }\end{array}$ & 15.4 & 14.9 & 15.3 & 15.1 & 17.6 & 17.4 \\
\hline
\end{tabular}

It was important to note that the increase of the aperture caused the numbers decrease of aperture lattices, so that anti compression capacity of honeycomb sandwich panels was weaken. The bending capacity and the capacity of the lateral load were also reduced with the number reduction of the aperture lattices.

\section{Conclusions}

The present paper discussed the preparation of the three kinds of continuous GF/PP honeycomb sandwich panels and analyzed the effect of honeycomb core structure on the mechanical properties of honeycomb sandwich panels. The increasing height of the honeycomb core, decreasing wall thickness of the honeycomb core and increasing aperture of the honeycomb core all can induce poor mechanical properties of the composite honeycomb sandwich panels.

\section{References}

1. $\mathrm{H} . \mathrm{Ku}, \mathrm{H}$. Wang, N. Pattarachaiyakoop, M. Trada, A review on the tensile properties of natural fiber reinforced polymer composites, Compos. Part B-Eng. 42 (2011) $856-873$.

2. H.L. Yin, X.Q. Peng, T.L. Du, J. Chen, Forming of thermoplastic plain woven carbon composites: An experimental investigation, J. Thermoplast. Compos. 28 (2015) 730-742.

3. F. Abbassi, I. Elfaleh, S. Mistou, A. Zghal, M. Fazzini,T. Djilali, Experimental and numerical investigations of a thermoplastic composite (carbon/PPS) thermoforming, Struct. Control Hlth. 18 (2011) 769-780.

4. G. Lebrun, M.N. Bureau, J. Denault, Thermoforming-stamping of continuous glass fiber/ polypropylene composites: interlaminar and tool-laminate shear properties, J. Thermoplast. Compos. 17 (2004) 137-165.

5. A.C. Long, C.E. Wilks, C.D. Rudd, Experimental characterisation of the consolidation of a commingled glass/polypropylene composite, Compos. Sci. Technol. 61 (2001) 1591-1603.

6. D.H. Kim, W.I. Lee, K. Friedrich, A model for a thermoplastic pultrusion process using commingled yarns, Compos. Sci. Technol. 61 (2001) 1065-1077.

7. F. Perrin, M.N. Bureau, J. Denault, J.I. Dicksona, Mode I interlaminar crack propagation in continuous glass fiber/polypropylene composites: temperature and molding condition dependence, Compos. Sci. Technol. 63 (2003) 597-607.

8. M. Sadighi, E. Rabizadeh, F.J. Kermansaravi, Effects of laminate sequencing on thermoforming of thermoplastic matrix composites, Mater. Process. Tech. 201 (2008) 725-730. 
9. M. Robert, R. Roy, B. Benmokrane, Environmental effects on glass fiber reinforced polypropylene thermoplastic composite laminate for structural applications, Polym. Composite. 31 (2010) 604-611.

10. J.P. Dear, H. Lee, S.A. Brown, rown S A. Impact damage processes in composite sheet and sandwich honeycomb materials, Int. J. Impact. Eng. 32 (2005) 130-154.

11. H. Ning, G.M. Janowski, U.K. Vaidya, Vaidya, G. Husman, Thermoplastic sandwich structure design and manufacturing for the body panel of mass transit vehicle, Compos. Struct. 80 (2007) 82-91.

12. C. Lu, M.Y. Zhao, L. Jie, J. Wang, Yu. Gao, X. Cui, P. Chen, Stress Distribution on Composite Honeycomb Sandwich Structure Suffered from Bending Load, Procedia Eng. 99 (2015) 405-412.

13. X.Y. Wang, F.B. Yang, J.C. Zhang, J.Y. Xiao, Design principle and application of sandwich structure composite material, Chemical Industry, Beijing, 2007, pp. 105-107. 